\title{
Teachers' Perspectives: Making Sense of Ethnic Nationalism, Ethnic Identity and Multicultural Education in South Korea
}

\author{
Young Mi Chang, ${ }^{1, *}$ \\ ${ }^{1}$ Ohio Dominican University, 1216 Sunbury Road, Columbus, OH 43219, USA \\ *Correspondence: Ohio Dominican University, 1216 Sunbury Road, Columbus, OH 43219, \\ USA. Tel: 1-614-251-4324 E-mail: changy@ohiodominican.edu
}

Received: January 28, 2015 Accepted: March 26, 2015 Published: April 10, 2015

doi:10.5296/ije.v7i2.7018ＵRL: http://dx.doi.org/10.5296/ije.v7i2.7018

\begin{abstract}
Historically, ethnic nationalism has played a central role in consolidating Koreans in times of hardship. This tendency continues today; as South Korea is transitioning from a homogeneous ethnic society to a multi-ethnic one, schools face a new challenge to embrace diversity. Oppressions that ethnic minority students experience are often associated with Korean ethnic nationalism. This study examines South Korean teachers' values and viewpoints regarding ethnic nationalism, and how these teachers make sense of ethnic nationalism in facing multicultural education and globalization. Participant teachers in this study overall believed that instilling strong Korean ethnic identity and pride would not conflict with enhancing multiculturalism, and identified various ways to accomplish these two aspects. Some felt the former should be implemented prior to the latter, while others indicated that concurrent integration of the two aspects would be preferable. The majority held that emphasizing a strong Korean ethnic identity would not oppress or disadvantage minority students. Teacher education programs for pre-service and in-service teachers should intentionally focus on critical reflection regarding one's group identity, as this may become a source of prejudice and unintentional oppression of members from different groups. The overarching goals of ethnic identity education and multicultural education should be established within the framework of social equity. The current status of "hybrid" based ethnic and national identity education should be challenged in that it tends to position the ethnic identity education separately from multicultural education. The two areas need to be integrated to embrace and affirm diversity.
\end{abstract}

Keywords: Ethnic nationalism, Ethnic identity, Diversity, Multiculturalism, South Korean Education 


\section{Introduction}

\subsection{Statement of Issue}

While the United States has a long history of immigration and is composed of people with diverse racial backgrounds, South Korea is a country that has historically been a homogeneous society with the absolute majority of the population of Korean ethnicity. However, increasing numbers of immigrants and international marriages have resulted in multicultural challenges in South Korea. Naturally, efforts and interests in multicultural education have been growing in South Korea (Lee, 2008). As multicultural education is interconnected with social, cultural and political contexts (Nieto \& Bode, 2012), multicultural education in South Korea has unique faces and challenges that are specific to South Korean society and culture, although there are similar patterns and elements shared with the United States and other countries.

Emphasis on national identity and ethnic nationalism are prevalent in South Korean society. For Koreans, national identity is regarded as the same as ethnic identity, due to the fact that Korea has been homogeneous in ethnicity throughout its long history (Shin, 2006a). "Real" Koreans are often defined as those who are ethnically, culturally and genetically descended from two Korean parents, and mixed raced people in Korea are often targets of discrimination in that they are not considered "pure-blooded or single-blooded." When referring to a person who is a Korean citizen with American ancestry, people generally say, "American, but born and raised in Korea," rarely referring to him or her as "American Korean." Similarly, many Koreans do not consider Korean citizens with Chinese origin in their ancestry as "real" Koreans. "Whakyo" is defined as a Chinese who resides in a foreign country; this term is commonly used to refer to Korean citizens with ethnically Chinese parents. Even if these persons have lived in Korea as Korean citizens for generations, many Koreans do not consider them "real" Korean but differentiate them as "Whakyo," which exemplifies Korean's criteria for and conceptualization of Korean ethnicity and nationality.

"Dangun Shinwha" (The myth of Founding King Dangun) is the symbolic folktale that defines the origin of the Korean nation as it presents Dangun as the descendent of the lord of heaven. This myth is taught in all grade schools for the purpose of shaping students' national identity. Along with this myth, there is a song about Dangun that contains the lyric: "We are one race. We Koreans are the proud descendants of Dangun" (Lee et al., 2006). Although this song is meant to foster unity and cooperation - since Koreans all descend from one ancestor, they should cooperate and help out each other-- multicultural students often feel isolated [by the song and context in schooling] (Lee et al., 2006), and they are often bullied and excluded (Seol et al., 2005).

It was not until 2007 that the Korean national curriculum committee re-examined the emphasis on "Danil-Minjok" (single-blooded ethnicity) in the textbook and removed this term from the history textbook. Most pre-service teachers and in-service teachers had attended their K-12 schools before this curriculum revision. This means that through their K-12 schooling, most teachers were taught to take pride in their cultural and ethnic homogeneity, because the national textbook described Danil-Minjok as one strength of Korea 
that helped the nation overcome numerous crises and become strong and cohesive. For instance, the pre-2007 national textbook emphasized that Koreans' minds were one--as a Danil-Minjok--to overcome the hardship under Japan's frequent attacks and during the colonial era.

"Ethnic nationalism will remain an important organizing principle of Korean society. We cannot ignore ethnic national identity or treat it as a mere myth or fantasy. But neither can we remain simply content with its current role. Instead, it should be recognized that ethnic nationalism has become a considerable force in Korean society and politics and that it can be dangerous and oppressive when fused with racism and other essentialist ideologies. Koreans must thus strive to find ways to use ethnic nationalism constructively and mitigate its potential harmful effects." (Shin, 2006a)

Strong ethnic national identity has been reinforced through schooling in Korea, which affects Korean people's mindsets consciously or unconsciously. An awareness of the historical roots of prejudice and an understanding of individual and institutional prejudice provide an essential framework for multicultural education (Ameny-Dixon, 2003). Dominance, superiority over others and ethnocentrism are constructed through various layers of ecological systems--through socialization in family, schooling and dominant cultural values. In order to examine the structural barriers to achieving equity, it is imperative to investigate the deeper root of dominance, the value system.

\subsection{Theoretical Framework}

Multicultural education should prepare students to critically reflect on the power and privileges of dominant culture and deconstruct them to create social equity. Jenks et al. (2001) identified three theoretical frameworks of multicultural education in teacher education, including conservative, liberal and critical multiculturalism. In the conservative multiculturalism framework, marginalized groups are expected to assimilate themselves into the mainstream culture (Gorski, 2009); their voices and perspectives are neither accepted nor appreciated (Mysore, 2013). The liberal multiculturalism framework operates on the value of pluralism and the respect of differences; however, it does not recognize power and privilege (Gorski, 2009). The critical multiculturalism framework, on the other hand, defines the goal of education in the sociopolitical context and focuses on the voices and perspectives of the underrepresented and oppressed in order to empower students to build social justice and equity (Gorski, 2009). Korean ethnic nationalism, historically being a tool of empowerment to deal with "stronger" countries' military, political, and economic invasion in the past, may now become a tool to tear down the identity of politically "weaker" ethnic minorities. Teachers' values and viewpoints are being perpetuated as hidden curriculum to students. Therefore, critical reflection on Korean ethnic nationalism is a vital first step in reaching the ultimate goal of multicultural education, social equity.

\subsection{Pre-Service and In-Service Teachers' Perspectives on Multicultural Education in Korea}

Few studies have examined the viewpoints and value system of teachers in transitioning to a diverse society and embracing multicultural education. A review of literature reveals that 
research and discourse on multicultural education in South Korea have focused on (i) The current status and goals of multicultural education in Korea and recommendations and directions for the future (Cho, 2008; Cho \& Yoon, 2010; Kim \& Kim, 2012; Mo \& Lim, 2012; Park \& Kwak, 2009), (ii) Multicultural education and curriculum from other countries compared with those of Korea (Choo, 2009; Kim, 2009), (iii) Difficulties faced by multicultural families (Kim \& Shim, 2007; Seol et al., 2005), (iv) Effectiveness of multicultural education programs for teachers and ways to increase teachers' multicultural efficacy and cultural competence (Chang, 2010; Chang \& Chung, 2009; Mo, 2009; Mo, Lee \& Lim, 2010).

Watson, Park and Lee (2011) examined pre-service teachers' awareness of and attitudes towards South Korea's increasing cultural diversity. They focused on the pre-service teachers' perceptions of multicultural issues in South Korean society and schools and multicultural education approaches. They reported that the majority of participants indicated that they felt undecided about the multiculturalization of South Korean society, and only around 20 percent expressed that they feel comfortable or very comfortable with multiculturalization. However, 95 percent responded that multicultural education is important, and about 70 percent disagreed or strongly disagreed with the perception of Korea's national identity as Danil-Minjok (Single blooded ethnic nation). The pre-service teachers' perceptions of multicultural education goals varied; goals included enhancing human relations and harmony, promoting assimilation, embracing other cultures and competitiveness in the global market.

Considering that practicing teachers' views on multicultural education reflect realities of complex contexts associated with their teaching, which pre-service teachers might not yet perceive, it is vital to study in-service teachers' perspectives on multicultural education.

Lee (2008) studied Korean elementary school teachers' conceptions of multicultural education, curriculum, and their perspectives toward implementing multicultural education at five Korean public elementary schools using a case study method. The common themes found in teachers' interviews regarding their perceptions of the goals of multicultural education included providing equal opportunities for children of undocumented foreign workers and children of international marriages in poor rural areas, increasing cultural awareness, developing positive racial and ethnic attitudes and enhancing global citizenship. As for the teachers' perceptions of the minority students, teachers of the children of undocumented foreign workers viewed these children as an educationally isolated group in that they saw these children as aliens who are different from Korean students and belong to their parents' countries. Regarding children from international marriages in rural areas (where Korean males, usually agrarian men in rural areas who do not have a good chance at marriage with a Korean female recruit their spouses from other Asian countries), the teachers' perception about the identity of internationally married families differed according to the nationality of the husband and wife. When the children's father was Korean and mother was foreign, teachers did not perceive these children to be deficient, so they did not provide any special education programs directly focusing on them. However, the teachers perceived children whose mother was Korean and father was foreign to be foreigners who would go to their father's country in the future; therefore, they were provided with or isolated in a special 
education class, and these children were more vulnerable to being marginalized in a hidden way than those whose father was Korean and mother was a foreigner. The children whose father was Korean and mother was foreign were considered to be Koreans, whereas the children whose father was foreign and mother was Korean were not considered Korean by the teachers in Lee's (2008) study.

Although the focus of Lee's (2008) study was not on examining the aspect of ethnic nationalism represented in schools, the finding about teachers' perception reflected in the teachers' criteria of defining Koreans based on the father's nationality (but not on the mother's nationality) may suggest that teachers' values are impacted by Korean's Confucius values entailing the patriarchal system being possibly compounded with ethnic nationalism. This finding shows a need for more study on the unofficial domain of multicultural education - teacher's perceptions and values. Because students' identity formation and self-esteem are influenced by social factors, and how schools acknowledge racial and ethnic identities will affect all students' educational experiences (Tatum, 1999), Korean teachers' perceptions of ethnic minority groups and their ethnic nationalism is a vital aspect to examine to enhance education equity.

Kim (2004) reviewed Korean high school social studies textbooks to examine how national identity is represented in Korean curriculum and found that three elements, including Korean ethnic identity, Korean reunification and globalization, are emphasized. Kim (2004) noted that textbooks focus on keeping the Korean identity while fitting to the globalized trend-having strong national identity and world citizenship at the same time--and that this is exemplified in a concept of open nationalism indicated in the $10^{\text {th }}$ grade textbook, which fosters world peace outwardly as it simultaneously enhances national solidarity inwardly. This tendency is also noted by So, Kim and Lee (2012) in their review of a newly revised national curriculum in 2009 (the implementation began in 2011). So, Kim and Lee stated that the new national curriculum aims at maintaining a strong ethnic identity while it pursues a Korean identity defined in the context of a multicultural, multiethnic global society, which is different from the past curriculum's stress on the oneness of Korea, a single culture and ethnicity. They also noted that defining a "hybrid" identity is to smooth over tensions between global values and traditional, ethnic values, considering that the new curriculum stressing the pluralistic values has been criticized for weakening character education involving values and traditions conventionally shared by Koreans. How teachers make sense of the "hybrid" identity and how they perceive the coexistence of two elements - strong ethnic identity and global citizenship - need to be studied further. Therefore, my study focused on Korean teachers' perspectives regarding Korean ethnic nationalism and multicultural education.

\section{Research Methods}

\subsection{Research Questions}

The focus of my study is to examine South Korean teachers' values and viewpoints regarding 
ethnic nationalism, and how they make sense of ethnic nationalism in facing multicultural education and globalization.

The following research questions are identified.

1. How is Korean ethnic nationalism reflected in Korean teachers' perspectives and in their educational experience?

2. How do teachers perceive the place of ethnic nationalism in education, in particular, in the multicultural education curriculum?

\subsection{Data Collection and Analysis}

Data collection for this study involved surveys of in-service teachers from various school districts in a major city and its satellite cities in South Korea. Survey questionnaires were distributed to different schools using both online and hard copies, because some teachers preferred online while others, hard copy format. Four teachers who were willing to support the data collection distributed the survey in their districts. Schools in the major city had little to no ethnic diversity, while those in its satellite cities had 20 to 40 percent of the school population being ethnic minority. This ensured participants' experiences with students' ethnic diversity would encompass a broader range. Participating teachers' teaching experience and their K-12 learning experience in respect to curricular contents would be typical of and similar to those of the general teacher population in South Korea, because the curriculum in South Korea is centralized. Participating teachers were all ethnic Korean, 46 males and 64 females. Twenty-nine of them teach in elementary school, 36 in middle school and 45 in high school.

A survey instrument was developed based on the research questions and a review of literature on multicultural education. The definition of ethnic nationalism for this study is based on Shin's (2006a, 2006b) description of Korean ethnic nationalism in his book, Ethnic Nationalism in Korea, and his article, Ethnic Pride Source of Prejudice, Discrimination. Shin's definition of this concept is expressed as:

(i) Korean ethnic nationalism is based on the sense of "a common bloodline and shared ancestry" (p. 2, 2006b)

(ii) "Belief in racially distinct and ethnically homogeneous nation" (2006a)

(iii) "A belief in a common prehistoric origin, producing an intense sense of collective oneness" (2006a)

(iv) "Korean's belief that they all belong to a unitary nation (Danil-Minjok), one that is ethnically homogeneous and racially distinctive." (2006a)

Developed items were re-shaped through expert reviews and pre-field testing to increase the internal validity of the survey questionnaire. The survey questionnaire included 10 multiple choice questions, including demographic and basic information about multicultural education in the participant's school, 15 Likert-scale questions and one open-ended question. For data analysis of survey items, frequency distributions were generated using SPSS. Interview data 
and open responses in the survey were analyzed based on grounded theory (Glaser \& Strauss, 1967). Through peer-debriefing process (Given, 2008), generated categories and assertions in my analysis were verified and triangulated.

\section{Findings and Discussions}

3.1 How is Korean Ethnic Nationalism Reflected in Korean Teachers' Perspectives and in Their Educational Experience?

The following survey questions were utilized in order to examine this research question.

How Korean ethnic nationalism is reflected in teachers' perspectives:

"I consider myself Korean ethnic nationalist."

"We, Koreans are one family-one people."

"It is more ideal if Korea is a nation with a single culture and ethnicity than when it is a multicultural and multiethnic nation."

"Korea is a preeminent nation in that we are one as a single blooded ethnicity."

"I am concerned about Korea's new identity becoming multiethnic/multicultural country."

How Korean ethnic nationalism is reflected in teachers' educational experience:

"I was taught in my grade schools that Korea is a preeminent nation in that we are one as a single blooded ethnicity."

"I was taught in my grade schools that Korean ethnicity is superior to other ethnicities."

"I was taught in my grade schools that we should take pride in being a member of Korean ethnicity."

Participants' responses to these statements are summarized in Table 1.

About 30 percent of the participants strongly agreed or agreed with the statement, "I consider myself Korean ethnic nationalist," while about 46 percent rated this item as Neutral, and about 24 percent strongly disagreed or disagreed with this statement. About 45 percent strongly agreed or agreed with "We, Koreans are one family-one people." For the statement, "It is more ideal if Korea is a nation with a single culture and ethnicity than when it is a multicultural and multiethnic nation," the majority of participants (57.3\%) strongly disagreed or disagreed with the statement. As for "Korea is a preeminent nation in that we are one as a single blooded ethnicity," 67 percent strongly disagreed or disagreed, while about 13 percent strongly agreed or agreed. Similarly, 61 percent of participants strongly disagreed or disagreed with "I am concerned about Korea's new identity becoming multiethnic/multicultural country," while about 17 percent strongly agreed or agreed. 
Table 1. Korean ethnic nationalism reflected in Korean teachers' perspectives and in their educational experience

\begin{tabular}{|c|c|c|c|c|c|c|}
\hline & $\begin{array}{l}\text { Strongly } \\
\text { Disagree } \\
\%(\mathrm{~N})\end{array}$ & $\begin{array}{l}\text { Disagree } \\
\%(\mathrm{~N})\end{array}$ & $\begin{array}{l}\text { Neutral } \\
\%(\mathrm{~N})\end{array}$ & $\begin{array}{l}\text { Agree } \\
\%(\mathrm{~N})\end{array}$ & $\begin{array}{l}\text { Strongly } \\
\text { Agree } \\
\%(\mathrm{~N})\end{array}$ & $\begin{array}{c}\text { Total } \\
\mathrm{N}\end{array}$ \\
\hline $\begin{array}{l}\text { I consider myself Korean ethnic } \\
\text { nationalist. }\end{array}$ & $\begin{array}{c}7.3 \% \\
(8)\end{array}$ & $\begin{array}{c}16.4 \% \\
(18)\end{array}$ & $\begin{array}{c}46.4 \% \\
(51)\end{array}$ & $\begin{array}{c}23.6 \% \\
(26)\end{array}$ & $6.4 \%(7)$ & 110 \\
\hline $\begin{array}{l}\text { We, Koreans are one family-one } \\
\text { people. }\end{array}$ & $\begin{array}{l}5.5 \% \\
(6)\end{array}$ & $\begin{array}{c}14.5 \% \\
(16)\end{array}$ & $\begin{array}{l}35.5 \% \\
(39)\end{array}$ & $\begin{array}{c}33.6 \% \\
(37)\end{array}$ & $\begin{array}{c}10.9 \% \\
(12)\end{array}$ & 110 \\
\hline $\begin{array}{l}\text { It is more ideal if Korea is a } \\
\text { nation with a single culture and } \\
\text { ethnicity than when it is a } \\
\text { multicultural and multiethnic } \\
\text { nation. }\end{array}$ & $\begin{array}{c}17.3 \% \\
(19)\end{array}$ & $\begin{array}{l}40 \% \\
(44)\end{array}$ & $\begin{array}{l}24.5 \% \\
(27)\end{array}$ & $\begin{array}{c}15.5 \% \\
(17)\end{array}$ & $\begin{array}{c}2.7 \% \\
(3)\end{array}$ & 110 \\
\hline $\begin{array}{l}\text { Korea is a preeminent nation in } \\
\text { that we are one as a single } \\
\text { blooded ethnicity. }\end{array}$ & $\begin{array}{c}21.8 \% \\
(24)\end{array}$ & $\begin{array}{l}39 \% \\
(43)\end{array}$ & $\begin{array}{c}27.3 \% \\
(30)\end{array}$ & $\begin{array}{c}10.9 \% \\
(12)\end{array}$ & $\begin{array}{c}0.9 \% \\
(1)\end{array}$ & 110 \\
\hline $\begin{array}{l}\text { I am concerned about Korea's } \\
\text { new identity becoming } \\
\text { multiethnic/ multicultural } \\
\text { country. }\end{array}$ & $\begin{array}{c}23.6 \% \\
(26)\end{array}$ & $\begin{array}{c}37.3 \% \\
(41)\end{array}$ & $\begin{array}{c}23.6 \% \\
(26)\end{array}$ & $\begin{array}{c}14.5 \% \\
(16)\end{array}$ & $\begin{array}{c}0.9 \% \\
(1)\end{array}$ & 110 \\
\hline $\begin{array}{l}\text { I was taught in my grade } \\
\text { schools that Korea is a } \\
\text { preeminent nation in that we are } \\
\text { one as a single blooded } \\
\text { ethnicity. }\end{array}$ & $\begin{array}{c}0.9 \% \\
(1)\end{array}$ & $\begin{array}{c}6.4 \% \\
(7)\end{array}$ & $\begin{array}{l}20.9 \% \\
(23)\end{array}$ & $\begin{array}{l}48.2 \% \\
(53)\end{array}$ & $\begin{array}{l}23.6 \% \\
(26)\end{array}$ & 110 \\
\hline $\begin{array}{l}\text { I was taught in my grade } \\
\text { schools that Korean ethnicity is } \\
\text { superior to other ethnicities }\end{array}$ & $\begin{array}{l}0.9 \% \\
(1)\end{array}$ & $\begin{array}{l}10 \% \\
(11)\end{array}$ & $\begin{array}{c}23.6 \% \\
(26)\end{array}$ & $\begin{array}{c}47.3 \% \\
(52)\end{array}$ & $\begin{array}{c}18.2 \% \\
(20)\end{array}$ & 110 \\
\hline $\begin{array}{l}\text { I was taught in my grade } \\
\text { schools that we should take } \\
\text { pride in being a member of } \\
\text { Korean ethnicity. }\end{array}$ & $\begin{array}{l}0 \% \\
(1)\end{array}$ & $\begin{array}{c}4.5 \% \\
(5)\end{array}$ & $\begin{array}{c}20.9 \% \\
(23)\end{array}$ & $\begin{array}{c}54.5 \% \\
(60)\end{array}$ & $\begin{array}{l}20 \% \\
(22)\end{array}$ & 110 \\
\hline
\end{tabular}

To sum, data indicated that the majority of teachers do not support the view of "single blooded" ethnicity being ideal and have no concern about Korea's new identity as a multiethnic and multicultural country, although nearly 45 percent hold a view that Koreans are one family-one people. One family-one people is the translated Korean term, "Han Kyoreh." "Han Kyoreh" can be defined as one ("Han") family/people ("Kyoreh") joined by a single ethnic origin, which implies the sentiment that Koreans are of a single race as Dangun's descendants (Jeong, 2001). Dangun nationalism, based on the Dangun myth depicting the origin of Korea's formation as a nation, has played a central role in raising national consciousness of Korean people for unified spirit in times of national hardships (Jeong, 2001). It appears that overall, although Dangun nationalism is not prevailingly represented in teachers' value systems, it still has its place for many teachers. Teachers' ratings regarding their educational experiences related to Korean ethnic nationalism seem to 
indicate that their perspective on ethnic nationalism has its roots in their socialized belief that may remain in teachers' value systems, although they are open to Korea becoming a multiethnic society. About 72 percent of the participants agreed or strongly agreed with the statement, "I was taught in my grade schools that Korea is a preeminent nation in that we are one as a single blooded ethnicity." About 65 percent agreed or strongly agreed with the statement, "I was taught in my grade schools that Korean ethnicity is superior to other ethnicities" and "I was taught in my grade schools that we should take pride in being a member of Korean ethnicity." Data on participants' education experiences of ethnic nationalism in Table 1 will be further discussed in the following section, along with Table 2, as the data regarding teachers' education experiences of ethnic nationalism were reflected upon in relation to the second research question below.

\subsection{How Do Teachers Perceive the Place of Ethnic Nationalism in Education and Multicultural Education Curriculum?}

The following Likert scale survey questions and an open ended question were utilized to address this research question.

"It is important to teach students to take pride in being a member of Korean ethnicity."

"It is important to teach students about the preeminence of Korean nation as a single blooded ethnicity."

"In order to foster a person who is "multicultural," the discourse on the preeminence of Korean ethnicity should be excluded from curriculum or informal teaching."

"It is important to instill strong Korean ethnic identity and pride in students through education."

"It is possible to instill strong Korean ethnic identity and pride in students through education and at the same time enhance students' multiculturalism through education."

"Multicultural education curriculum should focus on multicultural competences but at the same time it should support sustaining students' Korean ethnic identity."

"Emphasizing a strong Korean ethnic identity will oppress or give disadvantages to minority students."

An open ended question to examine this research question includes: How would you foster both strong ethnic identity and multiculturalism?

Findings based on participants' responses to the Likert scale survey questions are discussed next, followed by an analysis of the open ended question responses.

\subsubsection{Analysis of Likert Survey Question Responses}

The data on teachers' perception of ethnic nationalism in education and in multicultural education curriculum (Table 2) were interpreted by seeking patterns related to the responses for question items on teachers' experience of ethnic nationalism in their grade schools presented in Table 1. 


\section{Macrothink}

International Journal of Education

ISSN 1948-5476

2015, Vol. 7, No. 2

Table 2. Teachers' perception of ethnic nationalism in education and multicultural education curriculum

\begin{tabular}{|c|c|c|c|c|c|c|}
\hline & $\begin{array}{l}\text { Strongly } \\
\text { Disagree } \\
\%(\mathrm{~N})\end{array}$ & $\begin{array}{c}\text { Disagree } \\
\%(\mathrm{~N})\end{array}$ & $\begin{array}{c}\text { Neutral } \\
\%(\mathrm{~N})\end{array}$ & $\begin{array}{l}\text { Agree } \\
\%(\mathrm{~N})\end{array}$ & $\begin{array}{l}\text { Strongly } \\
\text { Agree } \\
\%(\mathrm{~N})\end{array}$ & $\begin{array}{c}\text { Total } \\
\mathrm{N}\end{array}$ \\
\hline $\begin{array}{l}\text { It is important to teach } \\
\text { students to take pride in } \\
\text { being a member of Korean } \\
\text { ethnicity. }\end{array}$ & $\begin{array}{c}3.6 \% \\
(4)\end{array}$ & $\begin{array}{c}12.7 \% \\
(14)\end{array}$ & $\begin{array}{c}38.2 \% \\
(42)\end{array}$ & $\begin{array}{c}38.2 \% \\
(42)\end{array}$ & $7.3 \%(8)$ & 110 \\
\hline $\begin{array}{l}\text { It is important to teach } \\
\text { students about the } \\
\text { preeminence of Korean } \\
\text { nation as a single blooded } \\
\text { ethnicity. }\end{array}$ & $\begin{array}{c}9.1 \% \\
(10)\end{array}$ & $\begin{array}{c}27.3 \% \\
(30)\end{array}$ & $\begin{array}{c}39.1 \% \\
(43)\end{array}$ & $\begin{array}{c}19.1 \% \\
(21)\end{array}$ & $\begin{array}{c}5.5 \% \\
(6)\end{array}$ & 110 \\
\hline $\begin{array}{l}\text { In order to foster a person } \\
\text { who is "multicultural," the } \\
\text { discourse on the } \\
\text { preeminence of Korean } \\
\text { ethnicity should be excluded } \\
\text { from curriculum or informal } \\
\text { teaching. }\end{array}$ & $\begin{array}{c}12.7 \% \\
(14)\end{array}$ & $\begin{array}{l}40 \% \\
(44)\end{array}$ & $\begin{array}{c}33.6 \% \\
(37)\end{array}$ & $\begin{array}{c}11.8 \% \\
(13)\end{array}$ & $\begin{array}{c}1.8 \% \\
(2)\end{array}$ & 110 \\
\hline $\begin{array}{l}\text { It is important to instill } \\
\text { strong Korean ethnic } \\
\text { identity and pride in } \\
\text { students through education. }\end{array}$ & $\begin{array}{c}2.7 \% \\
\text { (3) }\end{array}$ & $\begin{array}{c}8.2 \% \\
(9)\end{array}$ & $\begin{array}{c}49.1 \% \\
(54)\end{array}$ & $\begin{array}{c}32.7 \% \\
(36)\end{array}$ & $\begin{array}{c}7.3 \% \\
(8)\end{array}$ & 110 \\
\hline $\begin{array}{l}\text { It is possible to instill strong } \\
\text { Korean ethnic identity and } \\
\text { pride in students through } \\
\text { education and at the same } \\
\text { time enhance students' } \\
\text { multiculturalism through } \\
\text { education. }\end{array}$ & $\begin{array}{l}0 \% \\
(0)\end{array}$ & $\begin{array}{c}3.6 \% \\
(4)\end{array}$ & $\begin{array}{c}29.1 \% \\
(32)\end{array}$ & $\begin{array}{c}48.2 \% \\
(53)\end{array}$ & $\begin{array}{c}19.1 \% \\
(21)\end{array}$ & 110 \\
\hline $\begin{array}{l}\text { Multicultural education } \\
\text { curriculum should focus on } \\
\text { multicultural competences } \\
\text { but at the same time it } \\
\text { should support sustaining } \\
\text { students' Korean ethnic } \\
\text { identity. }\end{array}$ & $\begin{array}{l}0 \% \\
(0)\end{array}$ & $\begin{array}{c}3.6 \% \\
(4)\end{array}$ & $\begin{array}{c}35.5 \% \\
(39)\end{array}$ & $\begin{array}{c}37.3 \% \\
(41)\end{array}$ & $\begin{array}{c}23.6 \% \\
(26)\end{array}$ & 110 \\
\hline $\begin{array}{l}\text { Emphasizing a strong } \\
\text { Korean ethnic identity will } \\
\text { oppress or give } \\
\text { disadvantages to minority } \\
\text { students. }\end{array}$ & $\begin{array}{l}20 \% \\
(22)\end{array}$ & $\begin{array}{c}30.9 \% \\
(34)\end{array}$ & $\begin{array}{c}31.8 \% \\
(35)\end{array}$ & $\begin{array}{c}10.9 \% \\
(12)\end{array}$ & $\begin{array}{c}6.4 \% \\
(7)\end{array}$ & 110 \\
\hline
\end{tabular}

Participants' educational experiences of Korean ethnic nationalism were not necessarily reflected in their beliefs on their teaching of Korean ethnic nationalism. Despite more than 
seven out of ten ( 74.5 percent) responding that they were taught to take pride in being a member of Korean ethnicity (Table 1), fewer than five out of ten (about 46 percent) indicated that they strongly agreed or agreed that it is important to teach students to take pride in being a member of Korean ethnicity (Table 2). A similar pattern is found in their responses to the questions "I was taught in my grade schools that Korea is a preeminent nation in that we are one as a single blooded ethnicity" and "It is important to teach students about the preeminence of the Korean nation as a single blooded ethnicity." Whereas about 72 percent strongly agreed or agreed that they were taught in their grade schools that Korea is a preeminent nation in that they are one as a single blooded ethnicity (Table 1), only about 25 percent rated strongly agree or agree that it is important to teach about it (Table 2).

Although by and large, teaching about the concept of "single blooded ethnicity" was not deemed important, data suggest that Korean ethnic identity and pride were considered important aspects in education and multicultural curriculum by participants, as about 39 percent responded neutrally to "It is important to teach students about the preeminence of Korean nation as a single blooded ethnicity," with less than 25 percent strongly agreeing or agreeing, which means fewer than four in ten participants disagreed or strongly disagreed with this statement. However, more than 60 percent strongly agreed or agreed on the importance of sustaining students' Korean ethnic identity at the same time as focusing on multicultural competence in multicultural education. Fewer than 4 percent disagreed with this statement. The majority of participants believe that instilling strong Korean ethnic identity and pride does not conflict with enhancing multiculturalism. Nearly seven in ten (about 67 percent) strongly agreed or agreed that "It is possible to instill strong Korean ethnic identity and pride in students through education and at the same time enhance students' multiculturalism through education" with fewer than 4 percent disagreeing with this statement. In addition, the majority of participants expressed that the discourse on the preeminence of Korean ethnicity does not conflict with fostering a person who is multicultural. About 53 percent strongly disagreed or disagreed that "In order to foster a person who is "multicultural," the discourse on the preeminence of Korean ethnicity should be excluded from curriculum or informal teaching." It seems that the importance of preserving Korean ethnic identity and pride are reflected in teachers' value systems.

It may be that teachers are making sense of this transitional era by combining their ingrained habit of ethnic values and new global-cultural perspectives. This is consistent with So, Kim and Lee's (2011) notion that defining a "hybrid" identity is a way to adapt to changing values, smoothing over transitions between global values and ethnic values traditionally shared by Koreans. Although Dangun nationalism and its accounts of a single homogeneous race has declined with rapid Westernization and the prevalence of individualism and globalism, it still plays an essential role in Korea's unique political culture and aspiration for the achievement of unification of North and South Korea (Jeong, 2001). Responding to the criticism of unbalanced, heavy emphasis on fostering global citizens, the new national curriculum still emphasizes Korean ethnic and national identity education (So, Kim, \& Lee, 2011). It seems that sustaining ethnic nationalism is identified interchangeably with or confused with Korean ethnic and national identity education. Therefore, teacher education programs for pre-service 
and in-service teachers will need to focus on raising critical consciousness of their understanding of and borders between ethnic nationalism and ethnic identity, and what it means to support the development of students' ethnic identity.

The majority of participants (about 51 percent) strongly disagreed or disagreed that emphasizing a strong Korean ethnic identity will oppress or disadvantage minority students. It is likely that respondents are unable to recognize their own biases, as dominant group's privileges are often unnoticed and unacknowledged (McIntosh, 1988). Therefore, teacher education programs will need to focus on raising awareness of the dominant group's unearned privileges and to intentionally take multiple perspectives to transform their views. Critical examination of one's group identity is needed or else it may become a source of prejudice and unintentional oppression of members from different groups.

3.2.2 Analysis of Open Ended Question Responses: How Would You Foster Both Strong Ethnic Identity and Multiculturalism?

Analysis of teachers' responses to the open ended survey question, "How would you foster both strong ethnic identity and multiculturalism?" also revealed how teachers perceive the place of ethnic nationalism in education and multicultural education curriculum. Broadly, teachers' responses were grouped into two categories: first, a sequential paradigm and second, an integrative paradigm in making sense of the two aspects. A sequential paradigm involves teachers' belief that a solid foundation of ethnic identity needs to be established prior to multicultural education. An integrative paradigm entails teachers' view that ethnic identity and multicultural education need to be integrated together and sought simultaneously. Responses for each category are discussed next.

(I) Sequential Paradigm: Foundation First

Teacher's conceptual paradigm in this category emphasizes the establishment of ethnic identity prior to multicultural education. Responses in this category posit the importance of establishing cultural, ethnic esteem and identity as a foundational root, asserting the education of "root" of ethnic or national identity needs to come first as a base prior to implementing multicultural education.

Example responses for asserting a preference for ethnic identity education prior to multicultural education include:

"Multicultural education should be added, after well-grounded ethnic identity education. Ethnic identity education is to be implemented in a way that it is not excluding other culture and members of other culture but accepting and understanding them. At the elementary education level, it is too early to implement multicultural education and not appropriate. In case two aspects are to be implemented simultaneously, that should be carried out in schools consisting of extremely high populations of children from multicultural families."

"Based on self-respect and pride in our own culture and history, strengthen the importance of our roles and responsibilities in the global community in a globalizing world."

"Ethnic identity is a basis that is foundational, and multiculturalism is the identity's 
expansion."

"A variety of classes will be needed to promote students' esteem for and interest in our nation's culture (experience and acquisition of our nation's traditional culture such as food, music, musical instruments, etc.). And after that, enhance understanding and acceptance of other culture."

"If the ethnic identity is properly established, it would not be difficult to accept multiculturalism."

"If the student has well-established, solid ethnic identity that they are proud of, and there are multicultural students in the classroom, the student will naturally recognize and learn about other culture with ease."

Curriculum design and scope ordinarily expand from self to others, community, states, nations and world, reflecting students' developmental levels and interests (NCSS, 1988). Picower (2012) recommends six elements of social justice curriculum design for elementary classrooms, which move from (i) self-love and knowledge about themselves to (ii) respect for people different from themselves. The next three elements include (iii) issues of social justice, (iv) social movements and social change, (v) awareness raising, and (vi) social action. Picower (2012) suggests that it is critical to address elements one and two prior to embarking on the element three, because if students haven't been engaged in understanding their own strengths and deconstructing stereotypes about themselves and others through elements one and two, learning of topics on element three, the issues of oppression and social justice may end up causing cross group tensions. Relating sequential building of elements proposed by Picower (2012) to the data in the Sequential Paradigm, the responses acknowledge the importance of developing love for one's own heritage and culture as a primary element, and one of the responses, "Based on self-respect and pride in our own culture and history, strengthen the importance of our roles and responsibilities in the global community in a globalizing world" implies that learning self-respect serves the higher goal, global citizenship. However, gleaning from additional teacher responses, it seems that stronger emphasis is given to the ethnic identity establishment aspect than to multicultural education: "Multicultural education should be added, after well-grounded ethnic identity education...At the elementary education level, it is too early to implement multicultural education and not appropriate. In case two aspects are to be implemented simultaneously, that should be carried out in schools consisting of extremely high populations of children from multicultural families," "If the ethnic identity is properly established, it would not be difficult to accept multiculturalism," and "If the student has well-established, solid ethnic identity that they are proud of, and there are multicultural students in the classroom, the student will naturally recognize and learn about other cultures with ease."

It is questionable whether the participants emphasize this element (self-love) because it will build up to the higher goals of multiculturalism and global citizenship, or because the participants tend to position ethnic identity in the center, giving heavier weight to it while placing the multicultural education goals in a secondary scope. In order to make ethnic identity and multicultural education meaningful, it is imperative to define an interrelation 
between the two aspects. Multiculturalism, global citizenship and social justice should be embraced as ultimate goals that the establishment of healthy ethnic identity will lead into. Otherwise, ethnic identity education will continue to reinforce ethnic nationalism in South Korea.

An assumption undergirded in one of the responses for this paradigm listed above, "...At elementary education level, it is too early to implement multicultural education and not appropriate..." may be related to the participant's assumption on children's developmental trends: that as children get older, they become decentered and better able to understand a social world beyond their immediate environment (McDevitt \& Ormrodd, 2013). However, young children begin to develop an interest in the community and the world outside of their own, and they can learn beyond the scope of self, home, and family, only if the learning experience is meaningful (NAEYC, 1986). Cultural understanding, prejudices and attitudes about other ethnic groups are formed in early childhood, but a well-planned curriculum can result in fostering positive attitudes (Derman-Sparks \& Ramsey, 2005). By age nine or ten, children have well-established racial and ethnic prejudices (Joyce, 1970). If the sequential paradigm rigidly defines a timing gap between ethnic identity education and multicultural education, students may miss the optimum learning time to mold their views and attitudes towards cultural groups different from their own.

\section{(II) Integrative Paradigm}

Teachers in the integrative paradigm perceive that ethnic identity and multicultural education need to be integrated together and sought simultaneously. The integrative paradigm was further divided into subcategories, which include: (i) Assimilative citizenship education, (ii) Multicultural and global character development and (iii) Multicultural curriculum planning and development. Criteria for these subcategories involve levels of embracing other cultures, identifying and seeking specific plan, action or reform for multiculturalism and multicultural education.

(i) Assimilative citizenship education: In assimilative citizenship education, teachers' responses point out the "sameness" as a Korean citizen in integrating multicultural education and ethnic identity education. In this subcategory, teachers' responses do not involve the importance of embracing other cultures or identify any specific way or plan to seek multicultural education. Responses in this category mention the importance of citizenship education for all. Example responses include:

"In multicultural society they are people of our country and they are the same human beings, even if they have different nationalities; therefore, it is natural that they should be respected. In order for multicultural students to adjust well and live together in our society, rather than unconditional and one way pouring of compassion and giving to them, citizenship education will be needed that will help their understanding that they are equal citizens in the same country."

"I would suggest educating respects of two aspects (multiculturalism and ethnic identity). Multicultural students are Korean citizens too, so they need to be taught with rules that they 
follow in Korea, Korean history, culture and Hanguel (Korean literacy).”

(ii) Multicultural and global character development: In terms of multicultural and global character development, teachers' responses emphasize the importance of instilling dispositions and characters needed to accept other cultures and to be multicultural and global citizens, while promoting ethnic identity. Although the dispositional aspects are identified as important aspects to promote multiculturalism, teachers' responses do not involve specific level plans for accomplishing multicultural education. Responses in this category state that, along with education of ethnic identity, it is vital to foster multicultural and global citizen's character and disposition. Mentioning dispositional aspects in the context of changing society, world or globalization is coded as this category. Example responses include:

"Attitudes and disposition to accept other cultures can be taught; at the same time, they respect our own country's history and culture. Fostering compassion and thoughtfulness and being considerate of others and respectful will be important early on, and exposure to global citizenship education, as well."

"While instilling ethnic identity and esteem as Korean, at the same time, in the wave of globalization, raise the awareness of diverse culture, coexistence of multi-cultures, so that they don't develop discrimination. They have to be taught that it is not right to view other cultures as being inferior because theirs are different from our own, and they must have a mind filled with compassion and thoughtfulness."

"While educating ethnic identity, raise the awareness of multiculturalism in changing society."

"Educate and guide students on the way while respecting traditions, accepting the other culture and growing together."

(iii) Multicultural curriculum planning and development: In the area of multicultural curriculum planning and development, teachers' responses acknowledge the importance of embracing other cultures and identify specific level multicultural curriculum planning, development and instructional strategies. Teachers come up with different types of approaches in curriculum planning and development. Their suggested approaches were categorized and reflected in the light of Banks' (1989) integration of multicultural curriculum approaches, including Contribution (Heroes and Holidays), Additive, Transformation and Social Action.

In the Contribution approach, ethnic heroes, holidays or cultural events are added into pre-existing curriculum. Ethnic and multicultural contents are limited to special days, weeks or months related to ethnic events. In the Additive approach, ethnic contents, themes and perspectives are added into pre-existing curriculum without restructuring it. In the Transformation approach, the curriculum is restructured to infuse diverse ethnic perspectives and contents. In the Social Action approach, in addition to all of the elements of the Transformation approach, students are required to make decisions and take actions for social equity. Because these approaches are represented in a continuum, rather than distinct levels, it is not always clear-cut to differentiate teachers' responses into appropriate categories. Along 
with Banks' (1989) description of each approach, the extent of pervasiveness in integrating multicultural contents is reflected as criteria to determine the category. For example, it is considered Contribution, if the teacher's response addresses the integration of multicultural goals, contents or curriculum involving only certain periods of time (days or weeks). If the teacher's response discusses the integration of multicultural goals, contents and curriculum infused into multiple subject areas, or in every day curriculum rather than a separate lesson or unit from regular curriculum, it is categorized as Transformation. Example responses for each approach were as follows:

Contribution (Heroes and Holidays):

"Through multicultural education weeks."

Additive (Single subject and unit):

"On the theme of 'finding our roots' and 'the world as the earth that grows the root,' diverse ethnic identities bud out to establish multicultural education curriculum."

"For class themes, utilize problems caused when historically, ethnic identity was overemphasized, and how other countries like the United States integrate multiculturalism to be the world's successful country, in order to improve students' consciousness."

"In high school, the focus of curriculum is on college entrance preparation, so that if multicultural education is not in the regular curriculum, implementing multicultural education will be hard to accomplish. Even though it is a hard task, if I find a way to try, I think that it would be wise to utilize subject areas that fit well with multicultural education, including Ethics, Morals and Social Studies, and also it would be good to embed units on multicultural families in publishing textbooks. Another way could be the utilization of clubs run by schools and guided by teachers with expertise. However, the drawback is that clubs are not participated in by all students."

"One hour of Korean tradition class and another hour of multicultural education to promote mutual respect."

Transformation (Infusive and Pervasive):

"Infusion of two aspects in curriculum."

"For all subjects, multiculturalism related instructional unit can be added so that students learn both aspects seamlessly."

"Ethnic identity and multiculturalism are all important values in our lives. Education of our unique identity should be carried out in History, Language Arts, Physical Education, Arts and other various subjects. The same should apply to education of multiculturalism-it should be included within each subject area curriculum."

"Focus on cognitive process promoting multiple perspectives taking and interpreting things from different viewpoints."

"Taking different perspectives by dividing class hours." 


\section{Social Action:}

No response was coded as Social Action.

As seen in the findings above, a wide range of perspectives were manifested in teacher's responses, in terms of the need to embrace other cultures and curriculum change. In the Assimilative Citizenship Education perspective, what participants voiced aligns with the orientation of conservative multiculturalism described by Jenks, Lee and Kanpol (2001). Conservative multiculturalism supports the transmissions of cultures and social orders to mainstream society to which minorities are expected to conform and assimilate, while liberal multiculturalism values pluralism, and critical multiculturalism incorporates concerns and voices of minority groups and advocates equity where its meanings are not determined by the dominant culture but by diverse groups. Liberal multiculturalism is represented in teachers' voices in the second and third categories-(ii) Multicultural and global character development and (iii) Multicultural curriculum planning and development. Respect, acceptance of each other's culture and pluralism are reflected in comments in (ii) such as "Attitudes and disposition to accept other cultures can be taught, at the same time they respect our own country's history and culture..." and "...They have to be taught that it is not right to view other cultures as being inferior because theirs are different from our own, and they must have a mind filled with compassion and thoughtfulness." Pluralism based views are also evident in Transformation-Infusive in (iii), for example, "Ethnic identity and multiculturalism are all important values in our lives..." "Focus on cognitive process promoting multiple perspectives taking and interpreting things from different viewpoints." "Taking different perspectives by dividing class hours." However, teachers' responses did not entail critical multiculturalism in that they did not incorporate social justice and equity as an ultimate purpose or means to seek ethnic identity and multiculturalism. Teachers did mention the importance of taking multiple perspectives in Transformation-Infusive in (iii), which could have broadly implied focusing on the voices of the underrepresented and oppressed.

\section{Conclusion}

Participants in this study, by and large, consider Korean ethnic identity and pride as important aspects in education and multicultural curriculum, and do not define them as a barrier to multiculturalism. They also reveal some unconscious biases which could inadvertently negatively impact the effectiveness of their multicultural teaching. Therefore, the overarching goals of ethnic identity education and multicultural education should be critically examined and established in the framework of social equity. If ethnic identity is positioned in a separate realm from multicultural education, not as a building block to accomplish social equity, minority groups will continue to be marginalized. To avoid such marginalization, systematic development of multicultural education curriculum that integrates ethnic, local and global identity will be needed, and it should be built upon and reflect diverse groups' perspectives and voices, based on the premise of social equity. One of the limitations of conservative multiculturalism is that it tends to see culture as predetermined, unchanging and fixed sets of heritages and meanings to which minority groups are expected to assimilate (Banks \& Banks, 
2007). In preserving static national identity, it is likely that ethnocentrism is not being challenged, while other nations or ethnicities are being excluded. Without affirming diversity and without acknowledging the dynamic nature of culture, the attempt to firm ethnic identity will result in exclusion, oppression and inequity (Nieto \& Bode, 2012). Ethnic and national identity education should embrace diversity and multiculturalism. To that end, teacher education programs will need to engage students in defining the future direction of South Korean national identity, challenging the current status of a hybrid identity that preserves static, unchanging ethnic identity while "sometimes" promoting multiculturalism. In the hybrid paradigm, ethnic identity and multiculturalism are being placed in separate compartments. To move beyond this constrictive status, the two aspects should be integrated together to form a new identity - thereby making South Korea a nation of diversity and social equity.

\section{References}

Ameny-Dixon, G. M. (2003). Why multicultural education is more important in higher education now than ever. Retrieved from http://www.nationalforum.com/Electronic\%20Journal\%20Volumes/Ameny-Dixon,\%20 Gloria\%20M.\%20Why\%20Multicultural\%20Education\%20is\%20More\%20Important $\%$ 20in\%20Higher\%20Education\%20Now\%20than\%20Ever.pdf

Banks, J. A. (1989). Approaches to Multicultural Curriculum Reform. Trotter Review, 3(3), Article 5. Retrieved from http://scholarworks.umb.edu/trotter_review/vol3/iss3/5

Banks, J. A., \& Banks, C. A. M. (2007). Multicultural education: Issues and perspectives $\left(6^{\text {th }}\right.$ ed.). Hoboken, NJ: Wiley.

Chang, I. S. (2010). A study of the effectiveness on teacher training program of multicultural education. Seoul: Ministry of Education, Science and Technology.

Chang, I. S., \& Chung, K. M. (2009). Effects on prejudices and cognitions of anti-bias education program. Korean Education studies, 12(2), 103-129.

Cho, Y. D. (2008). A study on the actual practice of multicultural education program in school. The Report of Policies Study, Ministry of Education \& Human Resourced Development.

Cho, Y., \& Yoon, H. (2010). Korea's Initiatives in Multicultural Education Suggesting "Reflective Socialization". Retrieved from http://www.intlalliance.org/fileadmin/user_upload/documents/Conference_2010/NP-KO .pdf

Choo, B. H. (2009). Social integration study in Singapore: focus on the implications on morals and education. The Journal of Curriculum \& Evaluation, 12(3), 153-175.

Derman-Sparks, L., \& Remsey, P. (2005). What if all the children in my class are white? Young Children. Beyond the Journal. Retrieved from 
https://www.naeyc.org/files/yc/file/200511/DermanSparksBTJ1105.pdf

Given, L. M. (2008). The SAGE encyclopedia of qualitative research methods. Thousand Oaks, CA: SAGE Publications, Inc. http://dx.doi.org/10.4135/9781412963909

Glaser, B., \& Strauss, A. (1967). The discovery of grounded theory: Strategies for qualitative research. Chicago: Aldine.

Gorski, P. (2009). What we're teaching teachers: An analysis of multicultural teacher education coursework syllabi. Teaching and Teacher Education, 25, 309-318. http://dx.doi.org/10.1016/j.tate.2008.07.008

Jenks, C., Lee, J. O., \& Kanpol, B. (2001). Approaches to multicultural education in preservice teacher education: philosophical frameworks and models for teaching. Urban Review, 33(2), 87-105. http://dx.doi.org/10.1023/A:1010389023211

Jeong, Y. (2001). Myth of Dangun and 'Dangun Nationalism.' Paper presented at the Korean Society for Political Thought seminar at Sogang University, Seoul, Korea. Retrieved from http://www.koreafocus.or.kr/design1/layout/content_print.asp?group_id=653

Joyce, B. R. (1970). Social action for primary schools. Childhood Education, 46(5), 254-258. http://dx.doi.org/10.1080/00094056.1970.10727178

Kim, H. (2004). National identity in Korean curriculum. Canadian Social Studies, 38(3). Retrieved

from http://www2.education.ualberta.ca/css/Css_38_3/ARkim_national_identity_korean.htm

Kim, S. K., \& Kim, L. H. R. (2012). The need for multicultural education in South Korea. In D. A. Urias (ed.), The Immigration \& Education Nexus, 243-253. Boston, MA: Sense Publishers. http://dx.doi.org/10.1007/978-94-6091-820-9_15

Kim, S. M. (2009). The development of multicultural education policy in Germany. The Educational Policy Forum, 196, 16-21.

Kim, S., \& Shim, Y. (2007). Multicultural families in Korean rural farming communities: Social exclusion and policy response. Paper presented at the Fourth Annual East Asian Social Policy research network (EASP) International Conference, October2007, The University of Tokyo, Japan.

Lee, J. A., Heo, M., Park, J., \& Chun, J. (2006). Korea, cheering for Hines Ward but in classroom practice. Retrieved from http://www.hani.co.kr/arti/society/society_general/102573.html

Lee, J. M. (2008). Multicultural education in South Korean public elementary schools: An analysis of teachers' experiences and perspectives and school curriculum. Dissertation. Purdue University.

McDevitt, T. M., \& Ormrodd, J. E. (2013). Child development and education (5 ${ }^{\text {th }}$ ed.). Boston: Pearson. 
Mo, K. W. (2009). Effects of a teacher training program for multicultural education. The Journal of Korean Teacher Education, 26(2), 75-99.

Mo, K. W., \& Lim, J. (2012). Multicultural teacher education in Korea: Current trends and future directions. Multicultural Education Review, 5(1), 96-120.

Mo, K. W., Lee, H., \& Lim, J. (2010). Current status and future directions of multicultural teacher education in Korea. The Korean Journal of Multicultural Education, 1(1), 21-35.

Mysore, A. R. (2013). Multicultural curricular frameworks for preservice teachers. In J. Keengwe \& G. Onchwari (Eds.), Young immigrant learners (pp. 247-264). Hershey, PA: IGI Global.

NAEYC (1986). Position statement on developmentally appropriate practice in early childhood programs serving children from birth through age 8. Young Children (September), 4-19.

NCSS (1988). Social Studies for early childhood and elementary school children: Preparing for the $21^{\text {st }}$ century. Report from NCSS Task Force on early childhood/elementary Social Studies. Retrieved from http://www.socialstudies.org/positions/elementary

Nieto, S., \& Bode, P. (2012). Affirming diversity: The sociopolitical context of multicultural education. (6th ed.). Boston: Allyn and Bacon.

Park, S. H., \& Kwak H. Y. (2009). International comparative study of multicultural education policy to develop the policy of Korea. Theory and Research in Citizenship Education, 41(2), 97-127.

Picower, B. (2012). Using their words: Six elements of social justice curriculum design for the elementary classroom. International Journal of Multicultural Education, 14(1), 1-16.

Seol, D., Kim, Y., Kim H., Yoon, H. S., Lee, H., \& Yim, K. (2005). Foreign wives' life in Korea: Focusing on the policy of welfare and health. Korean Ministry of Health and Welfare.

Shin, G. (2006a). Ethnic pride source of prejudice, discrimination. The Korea Herald. $\begin{array}{llll}\text { Retrieved } & \text { August } & 2, & 2006\end{array}$ http://www.koreaherald.com/view.php?ud=20060803000016 and http://aparc.fsi.stanford.edu/news/koreas_ethnic_nationalism_is_a_source_of_both_prid e_and_prejudice_according_to_giwook_shin_20060802

Shin, G. (2006b). Ethnic nationalism in Korea: Genealogy, politics, and legacy, Stanford University Press, 2006. Translated into Korean, 2010 (한국 민족주의의 계보와 정치) 창작과 비평사.

So, K., Kim, J., \& Lee, S. (2012). The formation of the South Korean identity through national curriculum in the South Korean historical context: Conflicts and challenges. International Journal of Educational Development, 32, 797-804. http://dx.doi.org/10.1016/j.ijedudev.2011.11.005 
Tatum, B. D. (1999). Color Blind or Color Conscious: How schools acknowledge racial and ethnic identities will affect all students' educational experiences. The School Administrator. Retrieved May 1999 from http://www.aasa.org/SchoolAdministratorArticle.aspx?id=14892

Watson, S. L., Park, G. C., \& Lee, H. (2011). Pre-service teachers' awareness and attitudes on South Korea's increasing cultural and ethnic diversity and the role of multicultural education in K-12 schools. International Journal of Education, 3(2), 1-19. http://dx.doi.org/10.5296/ije.v3i2.709

\section{Copyright Disclaimer}

Copyright for this article is retained by the author(s), with first publication rights granted to the journal.

This is an open-access article distributed under the terms and conditions of the Creative Commons Attribution license (http://creativecommons.org/licenses/by/3.0/). 